\title{
Effect of Film Injection Location on Local Heat Transfer Coefficient on a Gas Turbine Blade
}

\author{
ANANT B. MEHENDALE, H. WANDA JIANG, SRINATH V. EKKAD and JE-CHIN HAN * \\ Turbine Heat Transfer Laboratory, Department of Mechanical Engineering, Texas A\&M University, \\ College Station, TX 77843, USA
}

(Received 10 March 1997; In final form 24 March 1997)

\begin{abstract}
Experiments were performed to study the effect of film hole location on local heat transfer coefficient distribution of a turbine blade model with air or $\mathrm{CO}_{2}$ film injection to simulate coolant density effect. Tests were performed on a five blade linear cascade at the chord Reynolds number of $3 \times 10^{5}$ at cascade inlet. The test blade had three rows of film holes in the leading edge region and two rows each on the pressure and suction surfaces. Film hole locations were varied by leaving the desired ones open and plugging the rest. A combination of turbulence grid and unsteady wake was used to generate upstream high turbulence condition. Results indicate that film injection by itself causes a substantial increase in Nusselt numbers over a blade model without film holes. An increase in mainstream turbulence intensity causes an increase in Nusselt numbers over most of the blade surface, for both coolants, and at all blowing ratios. Film injection promotes an earlier boundary layer transition on the suction surface and the onset of transition depends on the film injection location; but at high turbulence levels, transition location is almost independent of film injection location.
\end{abstract}

Keywords: Turbine Blade, Film Cooling, Heat Transfer, High Turbulence

\section{INTRODUCTION}

It is well known that gas turbine performance improves with an increase in turbine inlet temperature. This has caused a continuing trend towards higher gas turbine inlet temperatures and resulted in higher heat loads on turbine components. Hence, sophisticated turbine blade cooling techniques must be employed in order to maintain the engine performance requirements. Since any compressor extracted air for cooling degrades engine performance, the amount of coolant must be minimized. Thus, it is important to understand the effect of film hole location on local heat transfer coefficient distribution on a gas turbine blade. Mainstream turbulence generated by combustor and unsteady wakes shed by upstream nozzle vanes may have an adverse effect on film coverage and hence on film cooling performance. Also, the injectant to mainstream density ratio

\footnotetext{
* Corresponding author
} 
varies from 1.5-2.0. This study focuses on the effect of film hole location on local heat transfer coefficient distribution on a turbine blade model with air or $\mathrm{CO}_{2}$ film injection, under high mainstream turbulence conditions.

There have been many studies to investigate the effect of upstream unsteady wake and mainstream turbulence on heat transfer coefficients from a turbine blade without film cooling. Dunn [1986], Dunn et al. [1986,1989,1994], Blair et al. [1989a, 1989b], Abhari et al. [1992], and Blair [1994], conducted experiments in rotor-stator blade rows; whereas, Pfeil et al. [1983], Doorly and Oldfield [1985], Wittig et al. [1987,1988], Priddy and Bayley [1988], O'Brien and Capp [1989], Dullenkopf et al. [1991], Dullenkopf and Mayle [1994], Liu and Rodi [1992], and Han et al. [1993] did laboratory simulations of upstream unsteady wake conditions. They reported significant increases in heat transfer due to unsteady wake as well as an earlier and longer transition region on suction surface. The combined effect of mainstream turbulence and unsteady wake on heat transfer coefficients from a turbine blade without film cooling has been studied by Ashworth et al. [1985] and Doorly [1988]. Ashworth reported that in presence of unsteady wake, an increase in mainstream turbulence from $\mathrm{Tu}<1 \%$ to $\mathrm{Tu} \approx 4 \%$ moves transition on both pressure and suction surfaces from $50-60 \%$ of $\mathrm{X} / \mathrm{C}$ to about $10-30 \%$ of $\mathrm{X} / \mathrm{C}$. Doorly reported that the effect of unsteady wake passing on an already turbulent boundary layer heat transfer is fairly small.

There have been some studies to investigate the effect of upstream unsteady wake and mainstream turbulence on heat transfer coefficient from a turbine blade with film injection. Nirmalan and Hylton [1990] studied the effects of exit Mach number, exit Reynolds number, and coolant-to-gas pressure and temperature ratios on heat transfer coefficient on a vane. They reported that at low coolant-to-gas temperature ratio, the film cooling effects are relatively insensitive to exit Mach number but more sensitive to exit Reynolds number, and vice-versa. Camci and Arts [1990] studied the effects of coolant-to-gas temperature ratio, and mainstream turbulence on heat transfer coefficient. They reported heat transfer coefficient strongly depended on coolant-to-gas temperature ratio and mainstream turbulence did not have any significant effect. Abhari and Epstein [1994] studied heat transfer on a film cooled rotor blade with time resolved measurements, under simulated non-dimensional engine conditions in a blow down facility. They reported that film cooling reduces time-averaged heat transfer rate by as much as $60 \%$ on suction surface; whereas, the effect on pressure surface is relatively small. Ou et al. [1994] studied the effects of incident unsteady wake conditions and injectant density on blade heat transfer coefficient from a linear turbine blade cascade. They reported that an increase in unsteady wake strength causes an increase in heat transfer coefficient. Mehendale et al. [1994] studied the effects of incident unsteady wake conditions and injectant density on blade heat load for flow through a linear turbine blade cascade. They reported that higher density injectant at higher blowing ratios causes a larger reduction in heat loads to a blade. Ekkad et al. [1997] studied the combined effects of incident wake and mainstream turbulence on blade heat transfer coefficient and film effectiveness for the same blade used by $\mathrm{Ou}$ et al. [1994] and Mehendale et al. [1994].

Teekaram et al. [1989] studied the use of a foreign gas $\left(\mathrm{CO}_{2}\right)$ injection, to simulate density ratio effect, on film cooled heat transfer coefficients for flow over a flat plate. They compared data with $\mathrm{CO}_{2}$ or air (the injectant air was cooled to produce same density as $\mathrm{CO}_{2}$ ) as injectants. They did not observe any difference in heat transfer coefficients as long as the injectant density was maintained the same.

This study is a continuation of $\mathrm{Ou}$ et al. [1994], Mehendale et al. [1994], and Ekkad et al. [1997] who employed full film coverage, and $\mathrm{Ou}$ and $\mathrm{Han}$ [1994] who employed film injection through only a single row of film holes on pressure side and a single row of film holes on suction side. This investigation focuses on the effect of injection through only a few select film hole locations (to 
minimize injectant requirements) as compared to full film coverage, on local heat transfer coefficient distribution on a turbine blade model under high mainstream turbulence conditions for air or $\mathrm{CO}_{2}$ film injection. Jiang and Han [1996] presented the effect of injection location on film effectiveness for same blade geometry under same mainstream turbulence conditions.

The objectives of this study are to determine the changes in heat transfer coefficient distribution for - (1) film injection through three film hole rows, only in the leading edge region, (2) film injection through only one film hole row each, at $\mathrm{X} / \mathrm{C}=$ -0.13 and $\mathrm{X} / \mathrm{C}=0.18$, on the pressure and suction surfaces, respectively, (3) film injection through only one film hole row each, at $\mathrm{X} / \mathrm{C}=-0.2$ and $\mathrm{X} /$ $\mathrm{C}=0.41$, on the pressure and suction surfaces, respectively, (4) film injection through all the above mentioned film hole row locations (referred to as full film coverage in this paper), and (5) the effect of injectant to mainstream density ratio on blade heat transfer coefficient distributions.

\section{TEST APPARATUS AND INSTRUMENTATION}

The test apparatus consisted of a low speed, low turbulence, suction type wind tunnel with an inlet nozzle, a spoked wheel type wake generator, a turbulence grid, a linear turbine blade cascade with an instrumented blade at its center, and a blower. The wind tunnel was designed for a blade turning angle of $107.49^{\circ}$. The five blade cascade was installed downstream of the turbulence grid and the wake generator.

A detailed view of the test geometry is shown in Fig. 1. The cascade was designed for use in our low speed wind tunnel test facility. The blade and cascade configurations were designed to produce a similar velocity ratio distribution as in a typical advanced high pressure turbine blade row. The relative flow angles were $35^{\circ}$ and $-72.49^{\circ}$ at the blade inlet and exit, respectively. A five times scaled up model was used to simulate the engine Reynolds

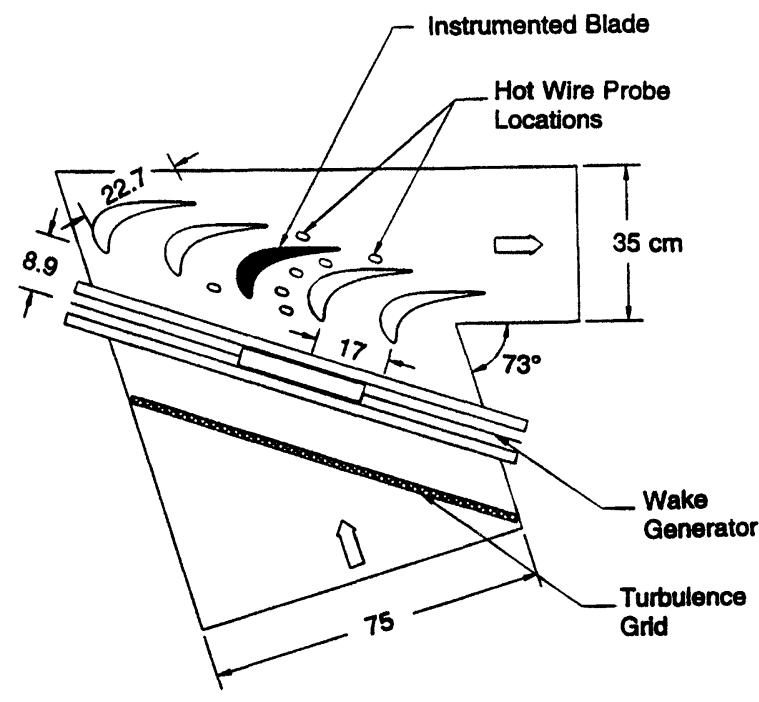

FIGURE 1 Schematic of test geometry.

number. The cascade had five blades, each with $22.68 \mathrm{~cm}$ chord length and $25.2 \mathrm{~cm}$ radial span. The blades were spaced $17.01 \mathrm{~cm}$ apart at the cascade inlet. All blades were fabricated from high quality model wood. Only the center blade was instrumented and had film holes.

A square mesh, square bar, biplaner turbulence grid was used to generate mainstream turbulence to simulate combustor turbulence. The turbulence grid had $0.5 \mathrm{~cm}$ square bars spaced $1.9 \mathrm{~cm}$ apart in both horizontal and vertical directions. The turbulence grid was located $30 \mathrm{~cm} \quad(x / b=63)$ upstream of the cascade leading edge.

The spoked wheel type wake generator had 32 rods, each $0.63 \mathrm{~cm}$ in diameter to simulate trailing edge of an upstream blade. Its shaft was located $20 \mathrm{~cm}$ below the bottom wall of the wind tunnel. Wake Strouhal number was set by controlling motor speed and measuring the wake generator rotation speed with a digital photo tachometer. The error caused by using non-linear rotating rods with a linear blade cascade was small [Ou et al., 1994].

Slots were machined in top wall of the wind tunnel for inserting flow measurement probes. Hot wire probe was inserted through slots near cascade entrance to measure oncoming flow velocity, turbulent fluctuations, and to check flow periodicity 
between adjacent flow passages. Exit flow velocity was measured through slots near cascade exit. Instantaneous velocity fluctuations at locations in the flow passages were measured through remaining slots. A calibrated single hot wire was used to measure instantaneous velocity profiles. It was connected to a 4-channel TSI IFA 100 hot wire anemometer. The anemometer signal was connected to a spectrum analyzer for displaying instantaneous velocity profile and frequency distribution. The signal was digitized by a $250 \mathrm{KHz} A / D$ board in a 386SX $20 \mathrm{MHz}$ machine.

A schematic of the top view of the test blade is shown in Fig. 2. Cavity 1 supplied three rows of film holes - one near the leading edge, and one each on pressure and suction surfaces. Cavity 2 supplied one row each on pressure and suction surfaces. Cavities 3 and 4 supplied one row of film holes on pressure and suction surfaces, respectively. Depending on its location, each row had 8 to 10 film holes between $30 \%$ and $70 \%$ of blade span.

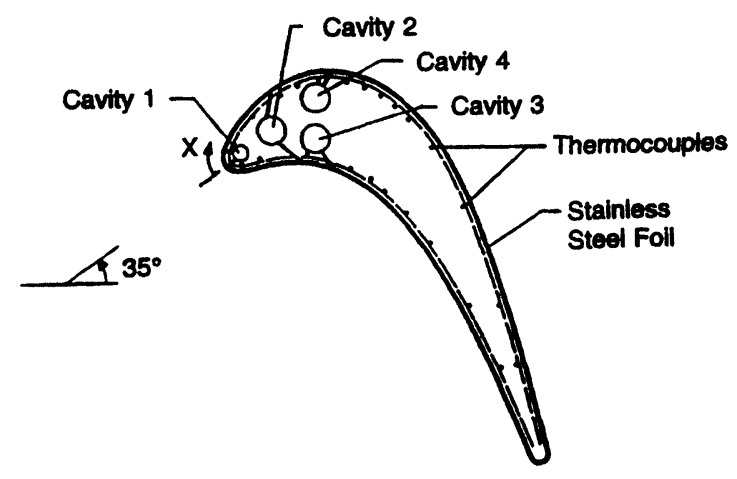

\begin{tabular}{|c|c|c|c|c|}
\hline $\begin{array}{l}\text { Film Hole Row } \\
\text { Location }\end{array}$ & $P / D$ & $\begin{array}{l}\text { Axial } \\
\text { Angle }\end{array}$ & $\begin{array}{l}\text { Radial } \\
\text { Angle }\end{array}$ & $\begin{array}{c}\text { Tangential } \\
\text { Angle }\end{array}$ \\
\hline Cavity 1: All Three & 7.31 & $90^{\circ}$ & $27^{\circ}$ & - \\
\hline Cavity 2: Pressure Side & 6.79 & - & $32^{\circ}$ & $55^{\circ}$ \\
\hline Cavity 2: Suction Side & 4.13 & - & $90^{\circ}$ & $45^{\circ}$ \\
\hline Cavity 3: Pressure Side & 5.00 & - & $35^{\circ}$ & $50^{\circ}$ \\
\hline Cavity 4: Suction Side & 5.71 & - & $90^{\circ}$ & $30^{\circ}$ \\
\hline
\end{tabular}

FIGURE 2 Schematic of test blade with film holes.
Some film holes had a compound angle (radial and tangential) relative to blade surface as seen in the figure. Radial angle is defined as the angle between film hole axis and local radial (spanwise) direction. Tangential angle is defined as the angle between film hole axis and local streamwise tangential direction. Details of film hole configuration (streamwise location, diameter, length, spanwise spacing, and compound angle) for this $5 \mathrm{X}$ model blade are typical of a gas turbine blade. Each cavity was connected with individually controllable injectant (air or $\mathrm{CO}_{2}$ ) supplies. Stainless steel foil strips $(25.4 \mathrm{~cm}$ long $\times 1.8 \mathrm{~cm}$ wide $\times 0.00378 \mathrm{~cm}$ thick $)$ were cemented vertically on the test blade except in the film hole regions where there was no foil. Instead, two layers of cellophane tape were used in these film hole regions to make the surface level with rest of the test surface. Holes were cut in the tape to match holes in the blade. The foils were separated by $0.8 \mathrm{~mm}$ gaps that were filled with wood putty and made flush with the foil surface. All foils were connected in series by copper bus bars. The foils provided an almost constant wall heat flux boundary condition, when heated electrically. Thirty-six gage copper constantan thermocouples were cemented on the undersides of the foils. There were 9 rows of thermocouples on the pressure surface and 13 rows on the suction surface. Each row had 4 thermocouples, two along adjacent hole centerlines and two along centerlines between adjacent holes, in the radial midspan region. Thermocouples were mounted in the injection cavities to measure the injectant flow temperatures just before injection. All thermocouples were connected to a 100 channel FLUKE 2285B datalogger interfaced with the 386SX machine. Input voltage and line current for both test blades were measured with a multimeter and a current clamp.

\section{TEST CONDITIONS AND DATA ANALYSIS}

All tests were performed at the chord Reynolds number ( $\mathrm{Re}$ ) of $3 \times 10^{5}$ at cascade inlet. The 
corresponding cascade inlet and outlet velocities were 21 and $50 \mathrm{~m} / \mathrm{s}$, respectively.

The injectant mass flux rate for a given row of injection holes was determined from the timeaveraged local mainstream velocity at that location (as measured with a pressure tap instrumented blade - Han et al. [1993]) and the desired blowing ratio. Tests were conducted at the blowing ratios of $0.5,1.0$, and 1.5. Film injection through the desired film hole rows was achieved by sealing film holes at other locations and making the surface flush with rest of the test surface.

Unsteady wake strength is given by wake Strouhal number $\mathrm{S}=2 \pi \mathrm{Ndn} /\left(60 \mathrm{~V}_{1}\right)$ (O'Brien and Capp, 1989). Two turbulence conditions at the cascade inlet were studied, the low turbulence condition $(\mathrm{Tu}=0.75 \%)$ where the turbulence grid and all rods from the wake generator were removed, and the high turbulence condition $(\mathrm{Tu}=16.4 \%)$. The integral length scale at cascade inlet for the turbulence grid was estimated to be about $1.1 \mathrm{~cm}$. Wake Strouhal number of $\mathrm{S}=0.3$ was achieved by setting $\mathrm{N}=287 \mathrm{rpm}$ which corresponds to a flow coefficient $\mathrm{V}_{1} / \mathrm{U}_{\mathrm{r}}=\mathrm{dn} /\left(\mathrm{r}_{\mathrm{m}} \mathrm{S}\right.$ ) (O'Brien and Capp, 1989) of 1.9.

During heat transfer tests, the stainless steel foils were electrically heated $\left(\mathrm{T}_{\mathrm{w}}\right.$ was in the $40-50^{\circ} \mathrm{C}$ range) and the injectant (air or $\mathrm{CO}_{2}$ ) temperature was maintained the same as the ambient mainstream temperature $\left(\mathrm{T}_{\infty}\right.$ was about $\left.25^{\circ} \mathrm{C}\right)$. As in $\mathrm{Ou}$ et al. [1994], local heat transfer coefficient with or without film injection was calculated from

$$
\mathrm{h}=\frac{\mathrm{q}_{\mathrm{gen}}^{\prime \prime}-\left(\mathrm{q}_{\text {cond }}^{\prime \prime}+\mathrm{q}_{\text {rad }}^{\prime \prime}\right)}{\mathrm{T}_{\mathrm{w}}-\mathrm{T}_{\infty}}=\frac{\mathrm{q}_{\text {gen }}^{\prime \prime}-\left(\mathrm{q}_{\text {cond }}^{\prime \prime}+\mathrm{q}_{\mathrm{rad}}^{\prime \prime}\right)}{\mathrm{T}_{\mathrm{w}}-\mathrm{T}_{\mathrm{aw}}} .
$$

Since Mach number $\ll 1, \mathrm{~T}_{\mathrm{aw}} \approx \mathrm{T}_{\infty}$. Heat loss tests were performed to estimate the total heat loss. The measured total heat loss was about $10 \%$ of the foil generated heat. On an average, the conduction and radiation heat losses were $4 \%$ and $6 \%$, respectively, of the heat generated. Heat loss through the tiny thermocouple wires was estimated to be very small (less than $0.1 \%$ ), and axial and lateral conduction through the thin foil was also found to be negligible.
Local Nusselt number $(\mathrm{Nu})$ was calculated from $\mathrm{Nu}=\mathrm{hC} / \mathrm{k}$. Local Nusselt numbers at a given streamwise location were averaged to obtain the spanwise averaged Nusselt number $(\overline{\mathrm{Nu}})$ at that location.

The above mentioned thin foil-thermocouple technique and the related data analysis method to calculate heat transfer coefficient are the same as in Ou et al. [1994]. At steady state, five sets of data were recorded at each location and averaged to minimize random errors. Similarly, five sets of data were recorded for the hot wire measurements. Measurement and estimation accuracies in voltage, current, wall temperature, and heat losses contributed to uncertainty in Nusselt number. An uncertainty analysis as in Kline and McClintock [1953] showed the uncertainty in Nusselt number to be about $\pm 5 \%$ based on $20: 1$ odds. Uncertainty in Nusselt number was a little higher at locations near the film holes due to lower wall temperatures and heat loss to injectant.

\section{RESULTS AND DISCUSSION}

Velocity profiles in the radial direction at the inlet and outlet of the left and right flow paths adjacent to the test blade are shown in Ou et al. [1994]. Results indicate that the inlet and outlet velocity profiles in the flow paths are essentially uniform in the midspan region. Also, the flow direction at the inlet and outlet of both flow paths was uniform. Thus, the Nusselt numbers are free from the top and bottom wall boundary layer effects. An identical profile blade with static pressure taps was used to measure local mainstream velocity around the blade. Local-to-exit velocity ratio $\left(\mathrm{V} / \mathrm{V}_{2}\right)$ distributions for several turbulence conditions are shown in Fig. 3. A pre-test prediction based on $\mathrm{Re}=2 \times 10^{5}$ is also shown for comparison. Results indicate that mean (time averaged) velocity distribution around the blade is almost same irrespective of the upstream turbulence condition. Flow over the suction surface experiences a strong acceleration over two thirds of axial 


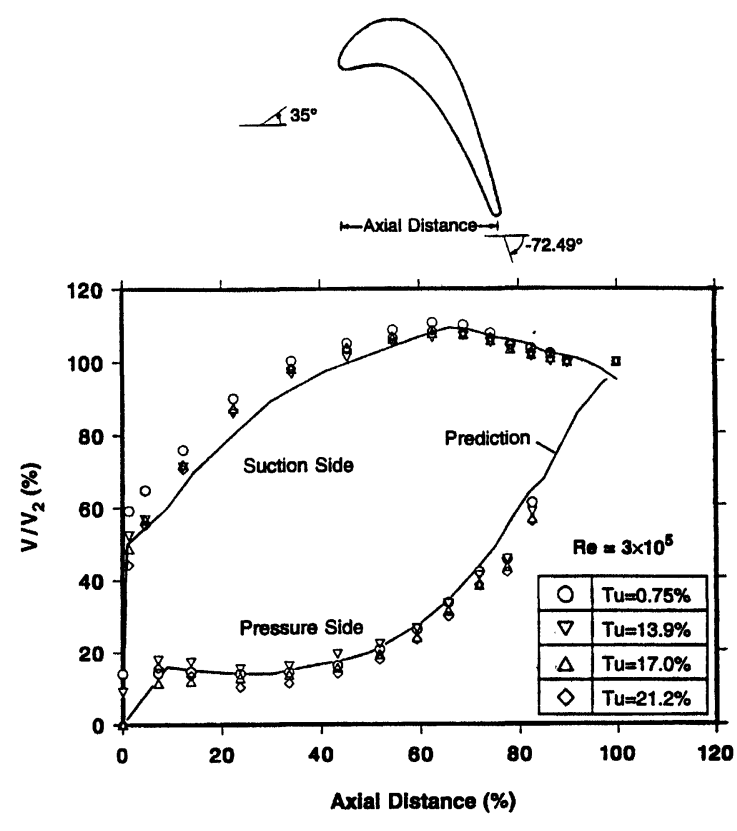

FIGURE 3 Effect of mainstream turbulence on local mainstream velocity.

distance followed by a deceleration. On the pressure surface, flow velocity remains almost constant till about one third of axial distance and then experiences an acceleration. Since the suction surface of a gas turbine blade experiences much higher mainstream velocities than its pressure surface, the boundary layer on its suction surface is much thinner and is more susceptible to mainstream and boundary layer disturbances. Hence, more attention is focussed on the effect of film hole location on suction surface heat transfer coefficients in discussion of the figures.

A turbine blade model without any film holes (smooth blade surface) was also fabricated and tested, in order to understand the effect of mainstream turbulence by itself. The effect of mainstream turbulence $(\mathrm{Tu}=0.75 \%$ and $16.4 \%)$ on spanwise averaged Nusselt number distribution for the blade without film holes is shown in Fig. 4. Also shown for comparison are the results at several other turbulence intensities. Results for the low mainstream turbulence base condition show that Nusselt number on the suction surface decreases

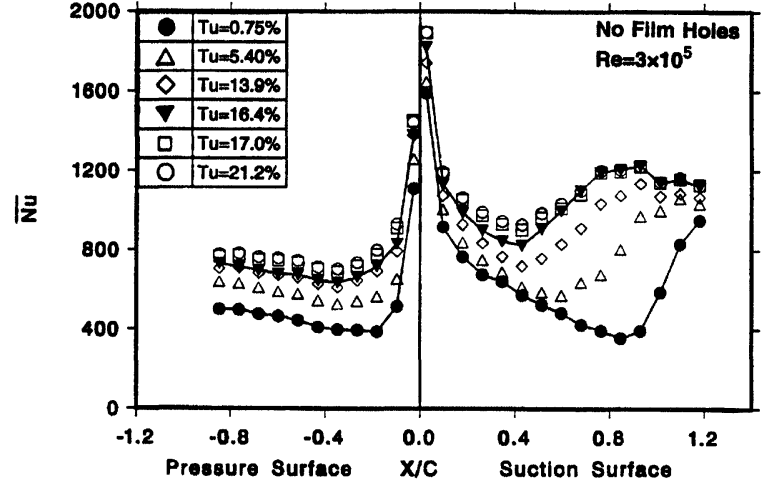

FIGURE 4 Effect of mainstream turbulence on Nusselt number distributions for the blade without film holes.

gradually with increasing streamwise distance from stagnation due to laminar boundary layer growth; but past $\mathrm{X} / \mathrm{C}=0.85$ (i.e. $85 \%$ chord), Nusselt number increases sharply due to boundary layer transition. For the same no grid condition, Nusselt number on the pressure surface decreases sharply with increasing $\mathrm{X} / \mathrm{C}$ (due to a much lower flow velocity and hence a faster boundary layer growth), but starts to increase from $\mathrm{X} / \mathrm{C}=-0.2$ due to a strong acceleration. As mainstream turbulence increases, the increased flow fluctuations disturb the boundary layer and cause an increase in heat transfer coefficient distribution over the entire blade surface. This effect is more severe on the suction surface than on the pressure surface. The upstream flow fluctuations cause an earlier laminar to turbulent boundary layer transition on the suction surface (at only half the distance as for the $\mathrm{Tu}=0.75 \%$ case) and the transition length increases (due to a strong acceleration in the midchord region which delays the production of turbulence spots) with increasing mainstream turbulence. The increases in heat transfer coefficients from $\mathrm{Tu}=0.75 \%$ to $\mathrm{Tu}=16.4 \%$ vary from $12 \%$ near the leading edge to as high as $230 \%$ at $\mathrm{X} / \mathrm{C}=0.85$ on the suction surface; whereas, the increases vary from $55 \%$ near the leading edge to $80 \%$ at $\mathrm{X} / \mathrm{C}=-0.2$ on the pressure surface.

Effect of blowing ratio and injectant density on spanwise averaged Nusselt number distribution, for film injection through holes in the leading edge 


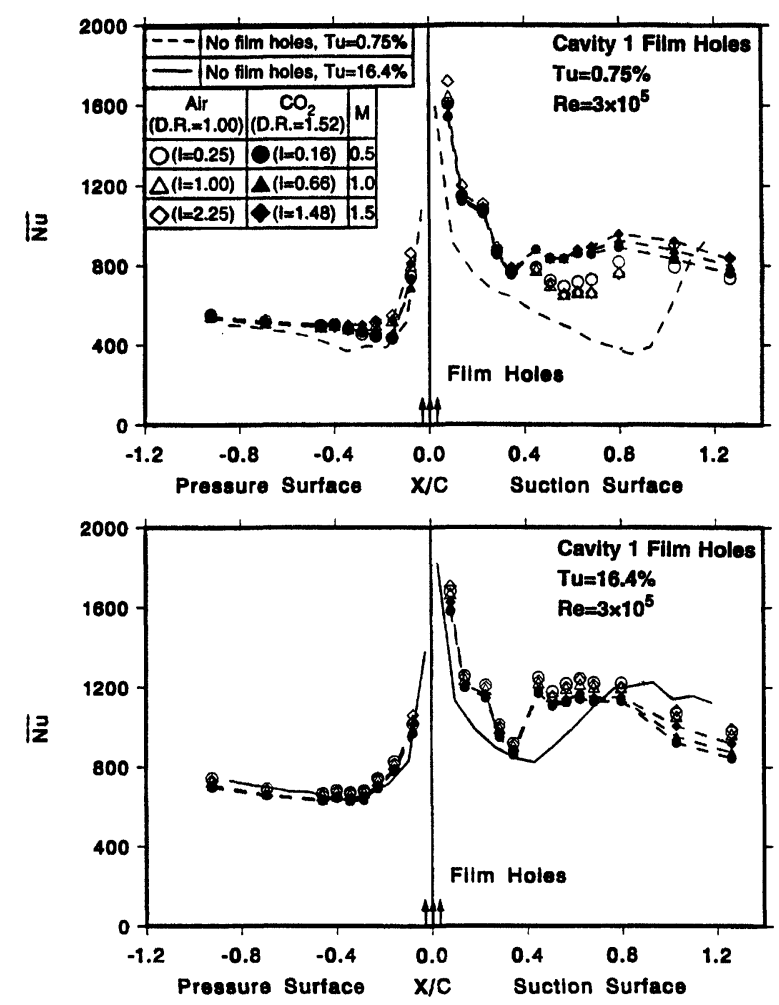

FIGURE 5 Effect of air or $\mathrm{CO}_{2}$ injection from the leading edge on Nusselt number distributions at $\mathrm{Tu}=0.75 \%$ and $\mathrm{Tu}=16.4 \%$.

region (Cavity 1), at the turbulence intensities of $\mathrm{Tu}=0.75 \%$ and $16.4 \%$ is shown in Fig. 5. Also shown for comparison are the results from the no film holes test model. For the case of $\mathrm{Tu}=0.75 \%$, increases in heat transfer coefficients over the no film holes model are observed downstream of the film hole row locations for both density ratio injectants at all blowing ratios. Subsequently, boundary layer growth and stabilization cause the heat transfer coefficients to decrease; but, at about $\mathrm{X} / \mathrm{C}=0.5$, the boundary layer disturbances due to leading edge film injection amplify and produce an earlier transition to turbulent boundary layer. Since a lower mainstream velocity produces a thicker boundary layer on the pressure surface, increases in heat transfer coefficients by flow disturbances due to film injection are less prominent on the pressure surface. As seen, just film injection by itself can significantly enhance heat transfer coefficients over the no film holes case. An increase in blowing ratio causes an increased injectant-mainstream interaction and results in an increase in heat transfer coefficients near film holes for both density injectants. For a given blowing ratio, as the injectant density increases the momentum flux ratio decreases. Hence, at a given blowing ratio, the lower density injectant jet (air, D.R. $=1.0$ ) penetrates further than the higher density injectant jet $\left(\mathrm{CO}_{2}\right.$, D.R. $\left.=1.52\right)$. This causes a higher jet-mainstream interaction for the lower density injectant and results in higher heat transfer coefficients. Effect of injectant density is seen just downstream of most of the film holes where heat transfer coefficients for air injection are slightly higher than for $\mathrm{CO}_{2}$ injection. Downstream of leading edge film holes $(\mathrm{X} / \mathrm{C} \approx 0.5)$ on the suction surface, this effect is reversed due to injectant accumulation within the boundary layer. The accumulation effect occurs because the higher density injectant $\left(\mathrm{CO}_{2}\right)$, with its lower momentum flux ratio, tends to stay in the boundary layer producing an even earlier transition and higher heat transfer coefficients. On the pressure surface, effect of blowing ratio or injectant density is not as significant as on the suction surface since the boundary layer is thicker and hence not as susceptible to boundary layer disturbances. At the higher turbulence intensity of $\mathrm{Tu}=16.4 \%$, the effect of film injection in increasing heat transfer coefficients over the no film holes case remains the same; but the effect of blowing ratio or injectant density is not as significant as at the lower mainstream turbulence level since the boundary layer is already highly disturbed. Also, transition occurs earlier at $\mathrm{X} / \mathrm{C}=0.4$ for both injectants and the accumulation region effect is diminished.

Effect of blowing ratio and injectant density on spanwise averaged Nusselt number distribution, for film injection through second rows of film holes on the pressure and suction surfaces (Cavity 2, $\mathrm{X} / \mathrm{C} \approx-0.12$ and $\mathrm{X} / \mathrm{C} \approx 0.19$ ), at the turbulence intensities of $\mathrm{Tu}=0.75 \%$ and $16.4 \%$ is shown in Fig. 6. Also shown for comparison are the results from the no film holes test model. Sharp increases 
in heat transfer coefficients are observed immediately downstream of the film hole row locations on the pressure and suction surfaces. They are caused by the highly disturbed boundary layer due to the injectant-mainstream interaction. Following such peaks, boundary layer growth and stabilization cause the heat transfer coefficients to decrease. As before (Fig. 5), increases in heat transfer coefficients over the no film holes model are observed downstream of the film hole row locations for both density ratio injectants at all blowing ratios and the increases in heat transfer coefficients on the pressure surface are less prominent. Unlike for the case of Cavity 1 injection (Fig. 5), transition occurs at about $\mathrm{X} / \mathrm{C}=0.4$ for both mainstream turbulence cases. This may be because the freestream acceleration is lower in this delayed injection region $(\mathrm{X} / \mathrm{C} \approx 0.2$ ) (as compared to leading edge injection). Hence, the boundary layer disturbances are not suppressed as in the previous case thus leading to an earlier transition even for low mainstream turbulence. The effects of blowing
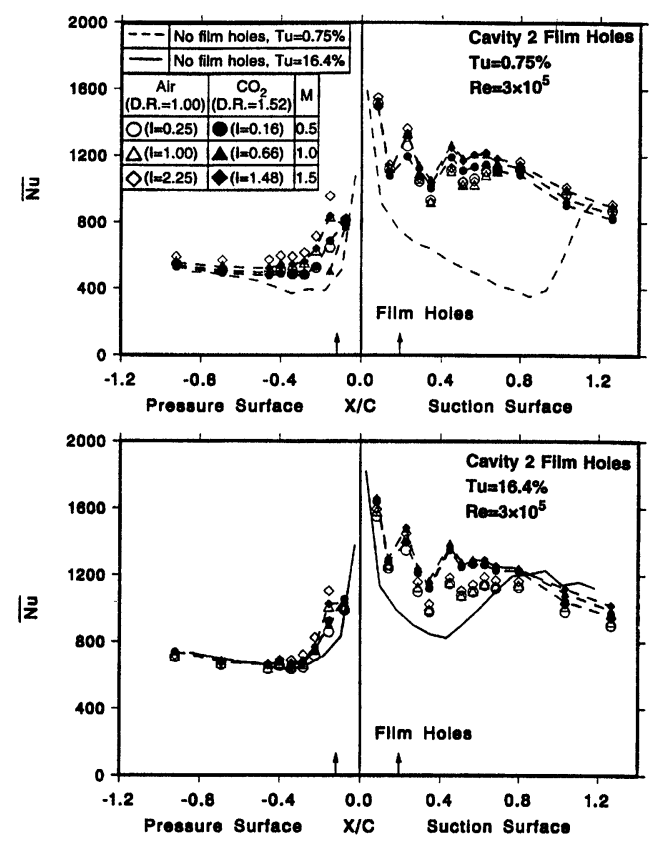

FIGURE 6 Effect of air and $\mathrm{CO}_{2}$ injection from the 2nd row on Nusselt number distributions at $\mathrm{Tu}=0.75 \%$ and $\mathrm{Tu}=16.4 \%$. ratio and density ratio are similar to the case of leading edge injection.

Mehendale et al. [1994] have shown that higher density injectant at higher blowing ratio provides best heat load reduction. Since density ratio and blowing ratio in a gas turbine engine are on the higher side, the performance of different film hole injection locations will be compared at the highest blowing ratio studied of 1.5 .

Effect of film hole row location on spanwise averaged Nusselt number distribution, for air injection at the blowing ratio of 1.5 , at the turbulence intensities of $\mathrm{Tu}=0.75 \%$ and $16.4 \%$ is shown in Fig. 7. Also shown for comparison are the results from Ou and Han [1994] for air injection $(\mathrm{M}=1.5)$ through third rows of film holes on the pressure and suction surfaces (Cavities 3 and 4), from Ekkad et al. [1997] for air injection $(M=1.2)$ through all rows of film holes (full coverage), and from the no film holes smooth surface blade model. For $\mathrm{Tu}=0.75 \%$, it can be seen that for the case of third rows injection, the data follows the no film
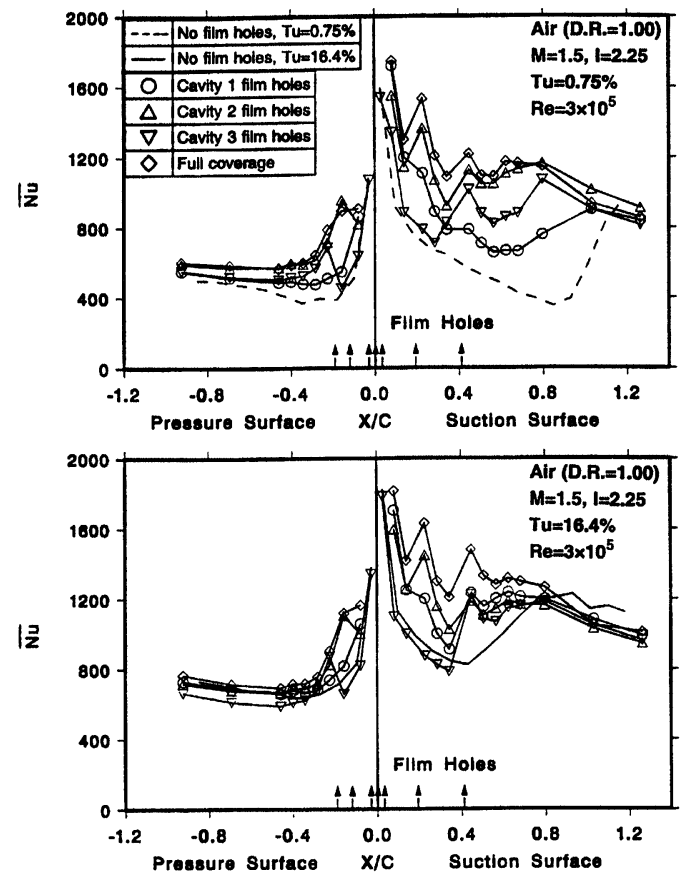

FIGURE 7 Effect of air film injection location on Nusselt number distributions at $\mathrm{Tu}=0.75 \%$ and $\mathrm{Tu}=16.4 \%$. 
holes data till just before injection location, then there is an increase in heat transfer coefficients followed by transition because of low mainstream acceleration. The data for leading edge injection is initially higher than for the third row injection, but it continues to decrease till transition $(\mathrm{X} / \mathrm{C}=0.7)$. The data for full coverage injection is higher than all other data in spite of being at a lower blowing ratio of only $M=1.2$. This is because, due to film injection through several rows boundary layer is disturbed repeatedly causing high heat transfer coefficients. The transition location moves upstream from smooth surface no film holes caseto-leading edge injection case-to-third rows injection case-to-second rows injection case-to-full coverage injection case. For $\mathrm{Tu}=16.4 \%$, the heat transfer coefficients at all locations are higher than at $\mathrm{Tu}=0.75 \%$ for all film hole location cases. One major difference over the low turbulence case is that transition occurs at about $\mathrm{X} / \mathrm{C}=0.6$ for all film hole location case. Another major difference over the low turbulence case is that past $\mathrm{X} / \mathrm{C}=0.4$, the leading edge, second rows, and third rows injection cases produce almost similar levels of heat transfer coefficients. This differences may be attributed to high mainstream turbulence effect dominating the boundary layer disturbance effects produced by discrete film injection for the leading edge, second rows, and third rows film injection cases.

Effect of film hole row location on spanwise averaged Nusselt number distribution, for $\mathrm{CO}_{2}$ injection at the blowing ratio of 1.5 , at the turbulence intensities of $\mathrm{Tu}=0.75 \%$ and $16.4 \%$ is shown in Fig. 8. Also shown for comparison are the results from $\mathrm{Ou}$ and $\mathrm{Han}$ [1994] for $\mathrm{CO}_{2}$ injection $(M=1.5)$ through third rows of film holes on the pressure and suction surfaces (Cavities 3 and 4), from Ekkad et al. [1997] for full coverage $\mathrm{CO}_{2}$ injection ( $\mathrm{M}=1.2)$, and from the no film holes test model. For $\mathrm{Tu}=0.75 \%$, the third rows injection data follows the no film holes data for air injection as observed in Fig. 7; but, the accumulation effects cause higher heat transfer coefficients than for air injection. Also, unlike for air injection at

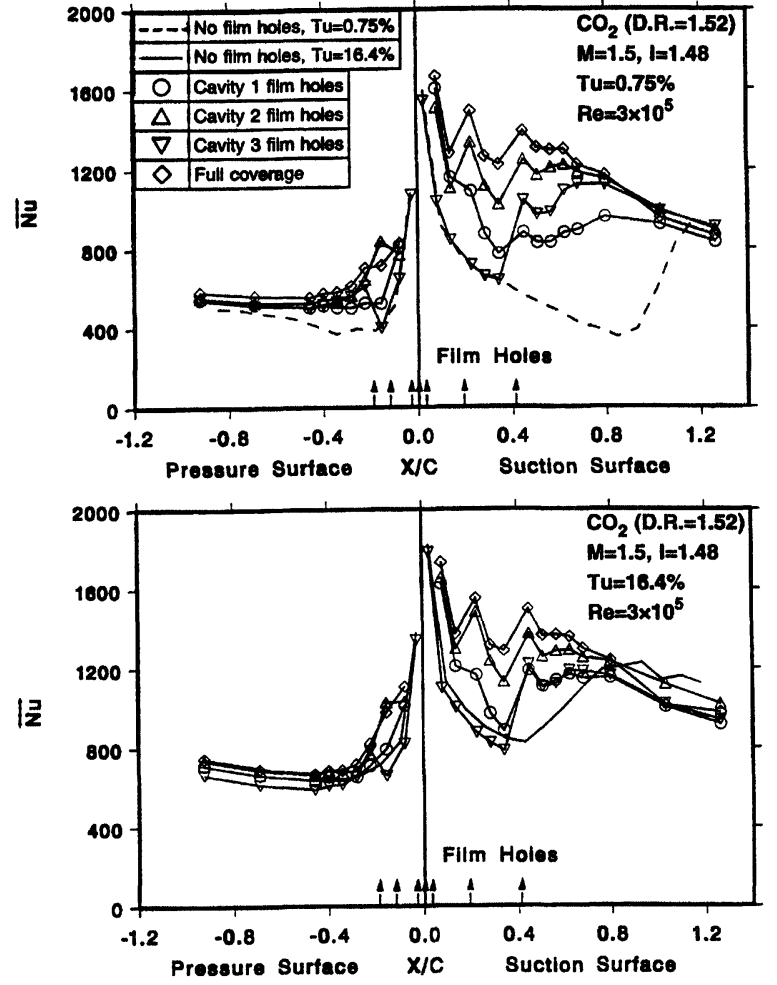

FIGURE 8 Effect of $\mathrm{CO}_{2}$ film injection location on Nusselt number distributions at $\mathrm{Tu}=0.75 \%$ and $\mathrm{Tu}=16.4 \%$.

$\mathrm{Tu}=0.75 \%$, transition occurs at about $\mathrm{X} / \mathrm{C}=0.5$ due to the accumulation effect. As for air injection, the full coverage injection case produces highest heat transfer coefficients followed by the second rows injection case followed by the leading edge injection and the third rows injection cases. As for the low turbulence case, transition occurs at $\mathrm{X} / \mathrm{C}=0.5$ for all injection cases at $\mathrm{Tu}=16.4 \%$. Also, the differences in heat transfer coefficients from case to case are considerably reduced.

Similar trends were observed at the two lower blowing ratios studied of $\mathrm{M}=0.5$ and 1.0 , but increases in heat transfer coefficient due to mainstream turbulence were more prominent at the lowest blowing ratio studied of $\mathrm{M}=0.5$.

Note: This study compares the effect of film hole row location on heat transfer coefficients. It should be kept in mind that heat transfer coefficient data forms a part of the ultimate goal to optimize film 
injection. When combined with the film effectiveness data (Jiang and Han, 1996), it provides the heat load (heat transfer) results. Thus, even though some film hole location case may produce high heat transfer coefficients, it may also provide high film effectiveness. This may result in lower heat loads than for some other film hole location cases which may produce lower heat transfer coefficients and lower film effectiveness.

\section{CONCLUDING REMARKS}

Effect of film hole row location on heat transfer coefficient distributions of a model turbine blade, with air (D.R. $=1.0)$ or $\mathrm{CO}_{2}($ D.R. $=1.52)$ film injection, in a linear cascade was investigated. Tests were performed at the chord Reynolds number of $3 \times 10^{5}$ at cascade inlet, at the mainstream turbulence intensities of $0.75 \%$ and $16.4 \%$ at cascade inlet, and at the blowing ratios of $0.5,1.0$, and 1.5 .

The main findings are:

1. For smooth surface (no film holes) blade, high mainstream turbulence promotes an earlier boundary layer transition and increases the transition length on the suction surface. Heat transfer coefficients on both pressure and suction surfaces increase with an increase in mainstream turbulence. These increases over the low turbulence data are much higher on the suction surface than on the pressure surface;

2. For film cooled blade, film injection by itself, i.e., for the low mainstream turbulence case, produces much higher heat transfer coefficients downstream of the injection locations;

3. Film injection promotes an earlier boundary layer transition. The onset of transition depends on film hole row location and also depends on the density of injectant, with higher density injectant causing an earlier transition;

4. Under high mainstream turbulence conditions, the onset of transition is independent of film hole row location;
5. The full coverage film injection case produces the highest heat transfer coefficients, followed by second rows film injection, followed by the leading edge and third rows film injections;

6. As mainstream turbulence increases, film cooled heat transfer coefficients over most of the blade surface increase;

7. As blowing ratio increases, heat transfer coefficients downstream of film injection locations increase;

8. Apart from causing an earlier transition, higher density injectant $\left(\mathrm{CO}_{2}\right)$ produces higher heat transfer coefficients in the transition region.

The effects of several important parameters (film injection location, mainstream turbulence, density ratio, and blowing ratio) on heat transfer coefficient distributions over a turbine blade model have been presented in this paper. The paper highlights the differences in effects of film hole locations on heat transfer coefficients. These results can be used in gas turbine blade design.

\section{Acknowledgment}

The project was sponsored by the Texas Higher Education Coordinating Board - Advanced Technology Program under grant number 999903-104.

\section{NOMENCLATURE}

b turbulence grid bar width

C blade chord length, straight distance between leading and trailing edge

d wake generator rọd diameter

D film hole diameter

D.R. density ratio (injectant to mainstream),

$$
\rho_{\mathrm{s}} / \rho_{\infty}
$$

h local heat transfer coefficient

I momentum flux ratio (injectant to mainstream $),\left(\rho \mathrm{V}^{2}\right)_{\mathrm{s}} /\left(\rho \mathrm{V}^{2}\right)_{\infty}$

$\mathrm{k} \quad$ local air thermal conductivity

M blowing ratio (injectant to mainstream mass flux ratio), $(\rho \mathrm{V})_{\mathrm{s}} /(\rho \mathrm{V})_{\infty}$

$\mathrm{n} \quad$ number of rods in the wake generator 
$\mathrm{N}$

wake generator rotation speed (rpm)

$\mathrm{Nu}$ local Nusselt number based on blade chord, hC/k

$\overline{\mathrm{Nu}} \quad$ spanwise averaged Nusselt number

$\mathrm{P} \quad$ film hole pitch

$\mathrm{q}_{\text {cond }}^{\prime \prime}$ local conduction heat loss flux

$\mathrm{q}_{\text {gen }}^{\prime \prime} \quad$ foil generated wall heat flux

$\mathrm{q}_{\text {rad }}^{\prime \prime} \quad$ local radiation heat loss flux

$r_{m} \quad$ distance between the wake generator shaft center and the cascade midspan

Re Reynolds number based on the blade chord, $\mathrm{V}_{1} \mathrm{C} / \nu$

$\mathrm{S} \quad$ wake Strouhal number, $2 \pi \mathrm{Ndn} /\left(60 \mathrm{~V}_{1}\right)$

$\mathrm{T}_{\mathrm{aw}}$ local adiabatic wall temperature

$\mathrm{T}_{\mathrm{s}} \quad$ injectant flow temperature within injection cavity

$\mathrm{T}_{\mathrm{w}} \quad$ local wall temperature

$\mathrm{T}_{\infty} \quad$ mainstream temperature at cascade inlet

$\mathrm{U}_{\mathrm{r}} \quad$ rotational velocity at the cascade midspan

$\mathrm{V}$ local mainstream velocity

$\mathrm{V}_{1} \quad$ mean mainstream velocity at cascade inlet

$\mathrm{V}_{2}$ mean mainstream velocity at the cascade exit

$\mathrm{x}$ distance between turbulence grid and cascade leading edge

$\mathrm{X}$ streamwise distance from stagnation along blade surface

$\nu$ kinematic viscosity

\section{References}

Abhari, R.S., Guenette, G.R., Epstein, A.H. and Giles, M.B., 1992. Comparison of Time-Resolved Measurements and Numerical Calculations, ASME Journal of Turbomachinery, Vol. 114, pp. 818-827.

Abhari, R.S. and Epstein, A.H., 1994. An Experimental Study of Film Cooling in a Rotating Transonic Turbine, ASME Journal of Turbomachinery, Vol. 116, pp. 63-70.

Ashworth, D.A., LaGraff, J.E., Schultz, D.L. and Grindrod, K.J., 1985. Unsteady Aerodynamics and Heat Transfer in a Transonic Turbine Stage, ASME Journal of Engineering for Gas Turbines and Power, Vol. 107, pp. 1022-1030.

Blair, M.F., Dring, R.P. and Joslyn, H.D., 1989a. The Effects of Turbulence and Stator/Rotor Interactions on Turbine Heat Transfer: Part I - Design Operating Conditions, ASME Journal of Turbomachinery, Vol. 111, pp. 87-96.

Blair, M.F., Dring, R.P. and Joslyn, H.D., 1989b. The Effects of Turbulence and Stator/Rotor Interactions on Turbine Heat

Transfer: Part II - Effects of Reynolds Number and Incidence, ASME Journal of Turbomachinery, Vol. 111 , pp. $97-103$.

Blair, M.F., 1994. An Experimental Study of Heat Transfer in a Large-Scale Turbine Rotor Passage, ASME Journal of Turbomachinery, Vol. 116, pp. 1-6.

Camci, C. and Arts, T., 1990. An Experimental Convective Heat Transfer Investigation Around a Film-Cooled Gas Turbine Blade, ASME Journal of Turbomachinery, Vol. 112, pp. 497-503.

Doorly, D.J. and Oldfield, M.L.G., 1985. Simulation of the Effect of Shock-Waves Passing on a Turbine Rotor Blade, ASME Journal of Engineering for Gas Turbines and Power, Vol. 107, pp. 998-1006.

Doorly, D.J., 1988. Modeling the Unsteady Flow in a Turbine Rotor Passage, ASME Journal of Turbomachinery, Vol. 110, pp. 27-37.

Dullenkopf, K., Schulz, A. and Wittig, S., 1991. The Effect of Incident Wake Conditions on the Mean Heat Transfer of an Airfoil, ASME Journal of Turbomachinery, Vol. 113 , pp. $412-418$.

Dullenkopf, K. and Mayle, R.E., 1994. The Effect of Incident Turbulence and Moving Wakes on Laminar Heat Transfer in Gas Turbines, ASME Journal of Turbomachinery, Vol. 116, pp. 23-28.

Dunn, M.G., 1986. Heat Flux Measurements for the Rotor of a Full-Stage Turbine: Part I - Time Averaged Results, ASME Journal of Turbomachinery, Vol. 108, pp. 90-97.

Dunn, M.G., George, W.K., Rae, W.J., Woodward, S.H., Moller, J.C. and Seymour, J.P., 1986. Heat Flux Measurements for the Rotor of a Full-Stage Turbine: Part II Description of Analysis Technique and Typical Time-Resolved Measurements, ASME Journal of Turbomachinery, Vol. 108 , pp. 98-107.

Dunn, M.G., Seymour, P.J., Woodward, S.H., George, W.K. and Chupp, R.E., 1989. Phase-Resolved Heat Flux Measurements On the Blade of a Full-Scale Rotating Turbine, ASME Journal of Turbomachinery, Vol. 111, pp. 8-19.

Dunn, M.G., Kim, J., Civinskas, K.C. and Boyle, R.J., 1994 Time Averaged Heat Transfer and Pressure Measurements and Comparison With Prediction for a Two-Stage Turbine, ASME Journal of Turbomachinery, Vol. 116, pp. 14-22.

Ekkad, S.V., Mehendale, A.B., Han, J.C. and Lee, C.P., 1997. Combined Effect of Grid Turbulence and Unsteady Wake on Film Effectiveness and Heat Transfer Coefficient of a Gas Turbine Blade with Air and $\mathrm{CO}_{2}$ Film Injection, $A S M E$ Journal of Turbomachinery, Vol. 119, pp. 594-600.

Han, J.C., Zhang, L. and Ou, S., 1993. Influence of Unsteady Wake on Heat Transfer Coefficient from a Gas Turbine Blade, ASME Journal of Heat Transfer, Vol. 115, pp. 904-911.

Jiang, H.W. and Han, J.C., 1996. Effect of Injection Location on Local Film Effectiveness on a Gas Turbine Blade, $A S M E$ Journal of Heat Transfer, Vol. 118, pp. 327-333.

Kline, S.J. and McClintock, F.A., 1953. Describing Uncertainties in Single-Sample Experiments, Mechanical Engineering, Vol. 75, pp. 3-8.

Liu, X. and Rodi, W., 1992. Measurements of Unsteady Flow and Heat Transfer In a Linear Turbine Cascade, ASME Paper No. 92-GT-323.

Mehendale, A.B., Han, J.C., Ou, S. and Lee, C.P., 1994 Unsteady Wake Over a Linear Turbine Blade Cascade with Air and $\mathrm{CO}_{2}$ Film Injection: Part II - Effect on Film Effectiveness and Heat Transfer Distributions, $A S M E$ Journal of Turbomachinery, Vol. 116, pp. 730-737. 
Nirmalan, V. and Hylton, L.O., 1990. An Experimental Study of Turbine Vane Heat Transfer with Leading Edge and Downstream Film Cooling, ASME Journal of Turbomachinery, Vol. 112, pp. 477-487

O'Brien, J.E. and Capp, S.P., 1989. Two-Component PhaseAveraged Turbulence Statistics Downstream of a Rotating Spoked-Wheel Wake Generator, ASME Journal of Turbomachinery, Vol. 111, pp. 475-482.

Ou, S. and Han, J.C., 1994. Unsteady Wake Effect on Film Effectiveness and Heat Transfer Coefficient from a Turbine Blade with One Row of Air and $\mathrm{CO}_{2}$ Film Injection, $A S M E$ Journal of Heat Transfer, Vol. 116, pp. 921-928.

Ou, S., Han, J.C., Mehendale, A.B. and Lee, C.P., 1994 Unsteady Wake over a Linear Turbine Blade Cascade with Air and $\mathrm{CO}_{2}$ Film Injection: Part I - Effect on Heat Transfer Coefficients, ASME Journal of Turbomachinery, Vol. 116, pp. $721-729$.

Pfeil, H., Herbst, R. and Schroeder, T., 1983. Investigation of the Laminar-Turbulent Transition of Boundary Layers
Disturbed by Wakes, ASME Journal of Engineering for Gas Turbines and Power, Vol. 105, pp. 130-137.

Priddy, W.J. and Bayley, F.J., 1988. Turbulence Measurements in Turbine Blade Passages and Implications for Heat Transfer, ASME Journal of Turbomachinery, Vol. 110, pp. 73-79.

Teekaram, A.J.H., Forth, C.J.P. and Jones, T.V., 1989. The Use of Foreign Gas to Simulate the Effect of Density Ratios in Film Cooling, ASME Journal of Turbomachinery, Vol. 111, pp. 57-62.

Wittig, S., Dullenkopf, K., Schulz, A. and Hestermann, R. 1987. Laser-Doppler Studies of the Wake-Effected Flow Field in a Turbine Cascade, ASME Journal of Turbomachinery, Vol. 109, pp. 170-176.

Wittig, S., Schulz, A., Dullenkopf, K. and Fairbank, J., 1988 Effects of Free-Stream Turbulence and Wake Characteristics on the Heat Transfer Along a Cooled Gas Turbine Blade, ASME Paper No. 88-GT-179. 


\section{ait \\ ENERGY MATERIALS}

M A N E Y publishing

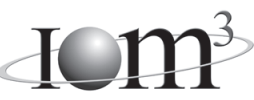

\section{Materials Science \& Engineering for Energy Systems}

Maney Publishing on behalf of the Institute of Materials, Minerals and Mining

The Institute of Materials, Minerals \& Mining

Economic and environmental factors are creating ever greater pressures for the efficient generation, transmission and use of energy. Materials developments are crucial to progress in all these areas: to innovation in design; to extending lifetime and maintenance intervals; and to successful operation in more demanding environments. Drawing together the broad community with interests in these areas, Energy Materials addresses materials needs in future energy generation, transmission, utilisation, conservation and storage. The journal covers thermal generation and gas turbines; renewable power (wind, wave, tidal, hydro, solar and geothermal); fuel cells (low and high temperature); materials issues relevant to biomass and biotechnology; nuclear power generation (fission and fusion); hydrogen generation and storage in the context of the 'hydrogen economy'; and the transmission and storage of the energy produced.

As well as publishing high-quality peer-reviewed research, Energy Materials promotes discussion of issues common to all sectors, through commissioned reviews and commentaries. The journal includes coverage of energy economics and policy, and broader social issues, since the political and legislative context influence research and investment decisions.

\section{CALL FOR PAPERS}

Contributions to the journal should be submitted online at http://ema.edmgr.com

To view the Notes for Contributors please visit: www.maney.co.uk/journals/notes/ema

Upon publication in 2006, this journal will be available via the Ingenta Connect journals service. To view free sample content online visit: www.ingentaconnect.com/content/maney

For further information please contact:

Maney Publishing UK

Tel: +44 (0)113 2497481 Fax: +44 (0)1132486983 Email: subscriptions@maney.co.uk

or

Maney Publishing North America

Tel (toll free): 8662975154 Fax: 6173546875 Email: maney@maneyusa.com

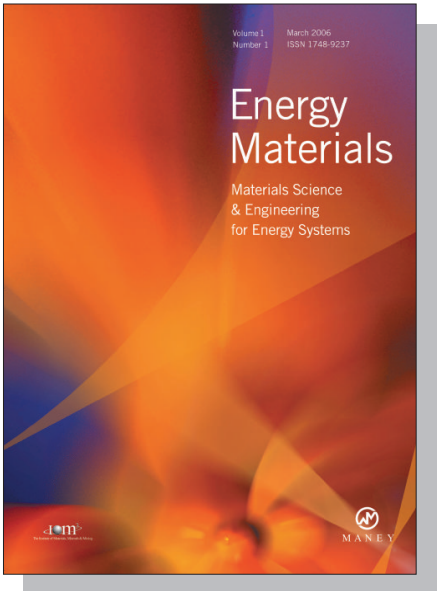

EDITORS

Dr Fujio Abe

NIMS, Japan

Dr John Hald, IPL-MPT, Technical University of Denmark, Denmark

Dr R Viswanathan, EPRI, USA

\section{SUBSCRIPTION INFORMATION}

Volume 1 (2006), 4 issues per year

Print ISSN: 1748-9237 Online ISSN: 1748-9245

Individual rate: $£ 76.00 / U S \$ 141.00$

Institutional rate: $£ 235.00 /$ US $\$ 435.00$

Online-only institutional rate: $£ 199.00 / U S \$ 367.00$

For special $\mathrm{IOM}^{3}$ member rates please email

subscriptions@maney.co.uk

\section{For further information or to subscribe online please visit www.maney.co.uk}



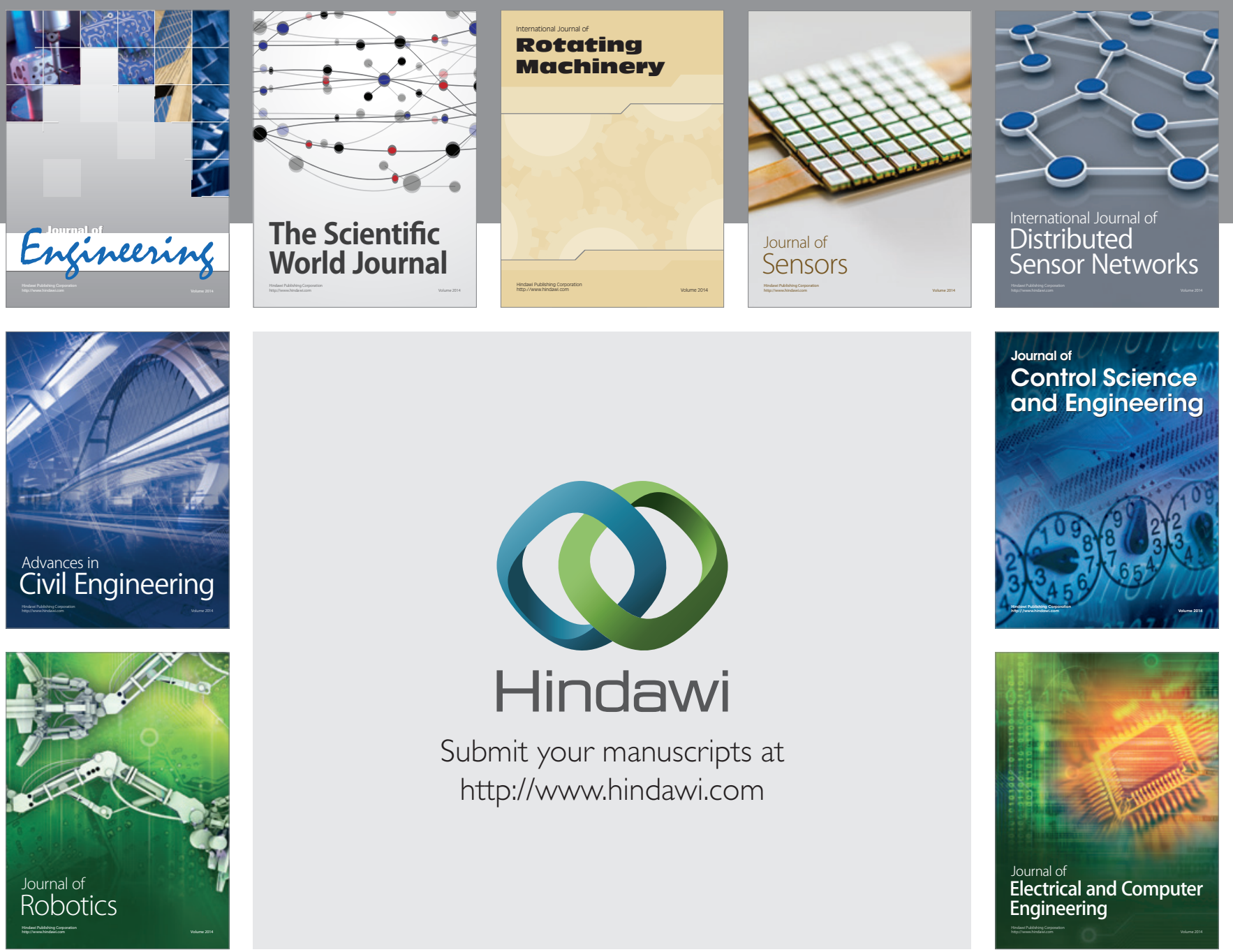

Submit your manuscripts at

http://www.hindawi.com
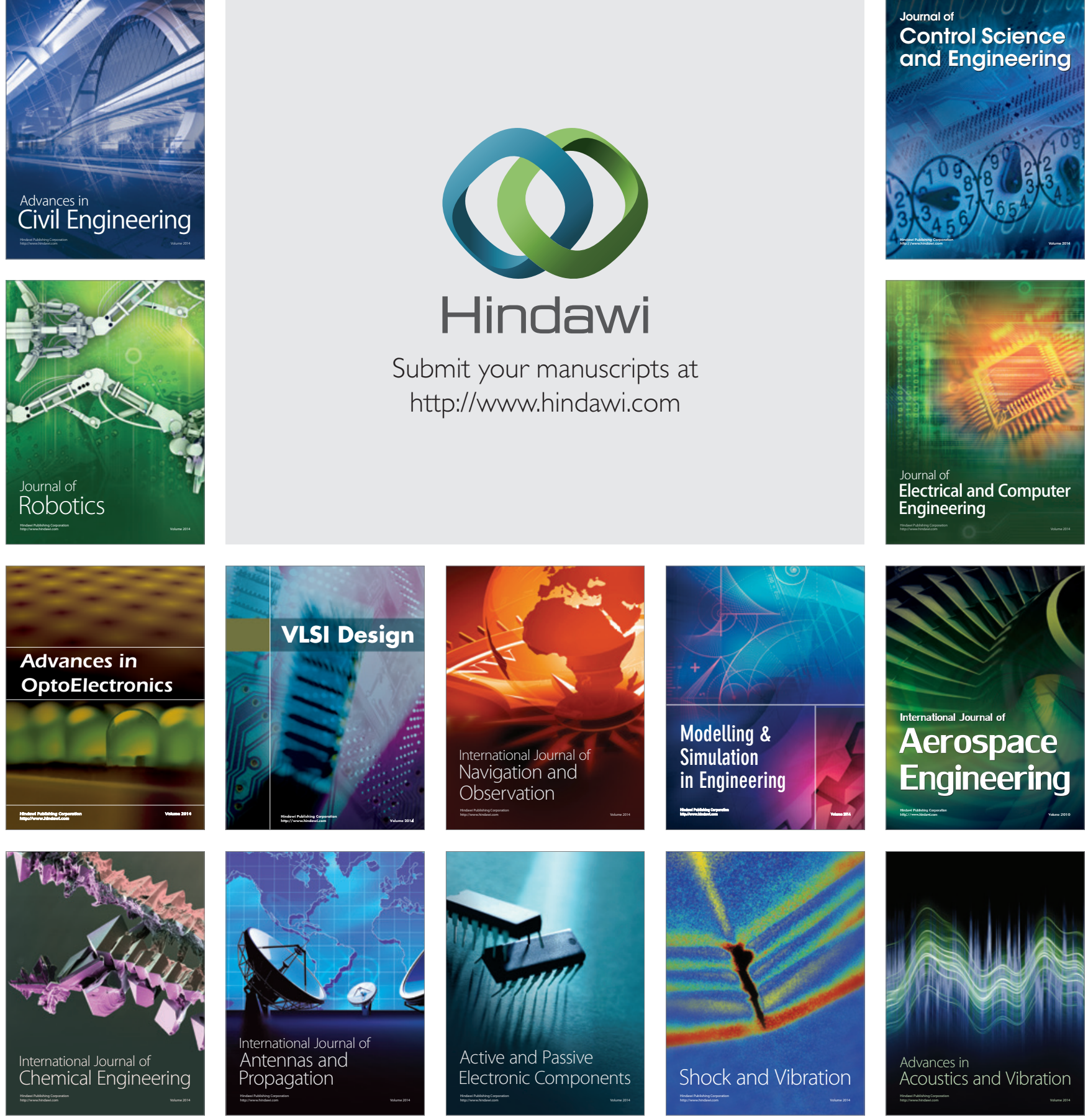